Article

\title{
New Cadinane Sesquiterpenes from the Stems of Kadsura heteroclita
}

\author{
Liang Cao ${ }^{1, \dagger}{ }^{\dagger}$ Nuzhat Shehla ${ }^{1,2, \dagger}$, Shumaila Tasneem ${ }^{1,2}$, Mengru Cao ${ }^{1}$, Wenbing Sheng ${ }^{1}$, \\ Yuqing Jian ${ }^{1}$, Bin Li ${ }^{1}$, Caiyun Peng ${ }^{1}$, M. Iqbal Choudhary 1,2,* Atta-ur-Rahman ${ }^{2}$, \\ Duan-fang Liao ${ }^{1}$ and Wei Wang ${ }^{1,2, *}$ \\ 1 TCM and Ethnomedicine Innovation \& Development International Laboratory, Innovative Materia Medica \\ Research Institute, School of Pharmacy, Hunan University of Chinese Medicine, Changsha 410208, China; \\ caoliang520945@126.com (L.C.); shehla_chm@hotmail.com (N.S.); tasneemshum@gmail.com (S.T.); \\ caomengru0913@126.com (M.C.); wbs626@126.com (W.S.); cpujyq2010@163.com (Y.J.); \\ libin_hucm@hotmail.com (B.L.); paudy@126.com (C.P.); dfliao@hnucm.edu.cn (D.-f.L.) \\ 2 H.E.J. Research Institute of Chemistry, International Center for Chemical and Biological Sciences, University \\ of Karachi, Karachi 75270, Pakistan; aurahman786@gmail.com \\ * Correspondence: iqbal.choudhary@iccs.edu (M.I.C.); wangwei402@hotmail.com (W.W.); \\ Tel.: +86-136-5743-8606 (M.I.C.); +92-21-4824924 or +92-21-4819010 (W.W.) \\ $+\quad$ They contributed equally to this work.
}

Received: 10 March 2019; Accepted: 26 April 2019; Published: 28 April 2019

check for updates

\begin{abstract}
As part of our continual efforts to exploit 'Tujia Ethnomedicine' for their pharmacophoric functionalities, we herein investigated Kadsura heteroclita collected from a deep Wulin mountain area in northern Hunan province. The current study resulted in the isolation of three new sesquiterpenes: $6 \alpha, 9 \alpha, 15$-trihydroxycadinan-4-en-3-one (1), (+)-3,11,12-trihydroxycalamenene (2), (-)-3,10,11,12-tetrahydroxy-calamenene (3), along with four known sesquiterpenes (4-7), and a cytochalasin $\mathrm{H}$ (8). Their chemical structures were elucidated by 1D-, and 2D-NMR spectroscopy, and HRESI-MS, CD spectrometry. The antioxidant, and cytotoxic activities of the compounds were evaluated. Compound 8 exhibited a strong antioxidant effect with an $\mathrm{IC}_{50}$ value of $3.67 \mu \mathrm{M}$ on isolated human polymorphonuclear cells or neutrophils.
\end{abstract}

Keywords: Kadsura heteroclita; Schisandraceae; sesquiterpenes; antioxidant; Tujia ethnomedicine

\section{Introduction}

In the last few decades, phytochemical work on the family Schisandraceae has resulted in a seminal contribution to novel structural frameworks for triterpenoidal skeletons [1-4]. Recently, some promising sesquiterpenes has also been reported from the plants of family Schisandraceae [5-10]. In our previous research, we reported the identification of several bioactive lignanoids from the genus kadsura [11] that highlight the immense diversity in the chemical constituents of these plants as well as in their important biological activities. Herein, we report the identification of three new sesquiterpenoids (1-3) from kadsura heteroclita, amongst compound $\mathbf{1}$ was a structural analogue of our previously reported compound 4, while compounds 2-3 possess calamenene core skeletons, which are identified for the first time from this species.

With the major distribution in China, genus Kadsura (Schisandraceaea) is represented by sixteen species, half of which are mainly distributed in the southwest and southeast part of China [12]. Kadsura heteroclita is a vine plant primarily distributed in the southwest part of China, has been used in Traditional Chinese Medicine (TCM) as "Hai Feng Teng" or "Ji Xue Teng" for the treatment of menstrual irregularities and blood deficiencies [13], by activating the blood circulation, relieving pain, and eliminating dampness. In the "Hu Ping" and "Xue Feng" mountain areas of northwest Hunan 
province, the stems of $K$. heteroclita are used to treat traumatic injuries and rheumatoid arthritis by one of the Chinese ethnic minorities known as the Tujia people [14,15]. Traditionally they named the stems of K. heteroclita as "Xue Tong" which means "circulating the blood system", which is used to treat blood related diseases [16]. These features triggered our research enthusiasm to explore the bioactive metabolites from this species that can be related to its clinical application. The previous work implied that the plant contains triterpenoids [17-19], lignans [20-22] and sesquiterpenes [6]. In the present work, we reported three new sesquiterpenes (1-3) (Figure 1) along with four known sesquiterpenes $6 \alpha, 9 \alpha$-dihydroxycadinan-4-en-3-one (4) [6], isoepicubenol (5) [23], cryptomeridiol (6) [24], $1 \beta, 4 \beta, 7 \alpha$-trihydroxyeudesmane (7) $[25,26]$, and a cytochalasin $\mathrm{H}(\mathbf{8})[27,28]$ isolated from the stems and roots of K. heteroclita as shown in Figure 1.

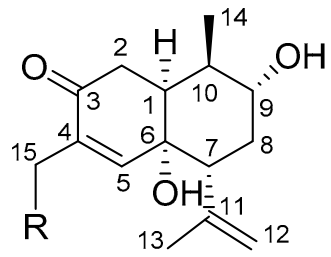

$1 \mathrm{R}=\mathrm{OH}$

$4 \mathrm{R}=\mathrm{H}$

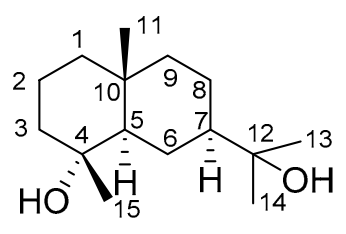

6<smiles>[R][C@]1(C)CC[C@H](C(C)(O)CO)c2cc(C)c(O)cc21</smiles>

$2 \mathrm{R}=\mathrm{H}$ $3 \mathrm{R}=\mathrm{OH}$

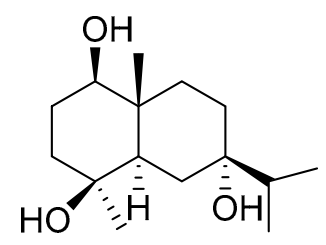

7<smiles>CC1=CC[C@]2(O)[C@@H](C)CC[C@H](C(C)C)[C@H]2C1</smiles>

5

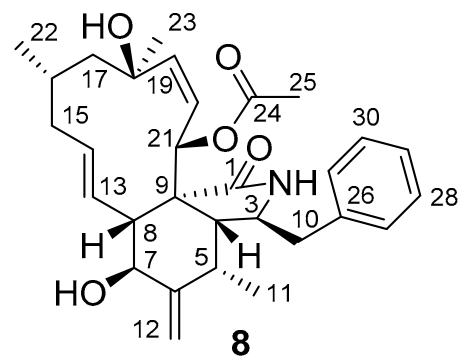

Figure 1. Structures of compounds 1-8.

\section{Results and Discussion}

\subsection{Structure Characterization of the Isolated Compounds (1-3)}

$6 \alpha, 9 \alpha, 15$-Trihydroxycadinan-4-en-3-one (1) (Figure 2) was isolated as a white amorphous powder. The molecular formula was established as $\mathrm{C}_{15} \mathrm{H}_{22} \mathrm{O}_{4}$ from its HRESI-MS $(\mathrm{m} / z 2289.1419 \text {, [M }+\mathrm{Na}]^{+}$ calcd. 289.1410), indicating five degrees of unsaturation. The ${ }^{1} \mathrm{H}-\mathrm{NMR}$ spectrum (Table 1 ) the revealed presence of one secondary group $\left(\delta_{\mathrm{H}} 1.00, \mathrm{~d}, J=6.9\right)$, a tertiary methyl group $\left(\delta_{\mathrm{H}} 1.83\right.$, s), one olefinic methine group $\left(\delta_{\mathrm{H}} 6.85, \mathrm{~s}\right)$, and a terminal olefinic methylene group $\left(\delta_{\mathrm{H}} 4.77,4.90\right.$, brs each) in the structure. The ${ }^{13} \mathrm{C}-\mathrm{NMR}$ and DEPT NMR spectra of compound $\mathbf{1}$ indicated fifteen carbon signals attributed to one carbonyl carbon $\left(\delta_{C} 200.5\right)$, four olefinic carbons $\left(\delta_{C} 155.2,146.6,137.0,114.6\right)$, and three oxygenated carbons $\left(\delta_{C} 73.3,71.9,59.5\right)$. Apart from these signals, three methines $\left(\delta_{C} 37.3,48.6\right.$, $50.2)$, two methylenes $\left(\delta_{C} 36.8,37.0\right)$, and two methyl groups $\left(\delta_{C} 15.0,23.0\right)$ were also observed. Besides the two double bonds and one carbonyl, the remaining two unsaturation degrees together with the chemical shift patterns suggested that the compound is a bicycle sesquiterpene based on a cadinane skeleton. A downfield chemical shift of an olefinic proton $\left(\delta_{\mathrm{H}} 6.85, \mathrm{~s}\right)$ conjugated with carbonyl carbon $\left(\delta_{C} 200.5\right)$ showed the presence of an $\alpha-\beta$ unsaturated ketone moiety in the skeleton of $\mathbf{1}$.

By carefully comparing the ${ }^{1} \mathrm{H}$ - and ${ }^{13} \mathrm{C}-\mathrm{NMR}$ chemical shifts data (Table 1 ) of $\mathbf{1}$ with that of known compound $6 \alpha, 9 \alpha$-dihydroxycadinan-4-en-3-one (4), which was also reported previously from $K$. heteroclita [6], we revealed the major difference between the two structures. The chemical shift of $\mathrm{C}-15\left(\delta_{\mathrm{C}} 15.3, \delta_{3 \mathrm{H}} 1.81,3 \mathrm{H}\right)$ corresponding to a methyl group in 4 changed to oxygenated methylene $\left(\delta_{\mathrm{C}} 59.5, \delta_{2 \mathrm{H}} 4.16,2 \mathrm{H}\right)$ in 1 . This deduction was supported by HMBC correlations of $\mathrm{H}_{2}-15$ with $\mathrm{C}-3$ $\left(\delta_{C} 200.5\right), C-4\left(\delta_{C} 137.0\right)$, and $C-5\left(\delta_{C} 155.2\right)$. An isopropenyl unit was also identified in the skeleton 
on the basis of the presence of terminal methylene $\left(\delta_{\mathrm{C}} 114.6, \delta_{\mathrm{H}} 4.77,4.90 \mathrm{brs}\right.$ each), a tertiary methyl signal $\left(\delta_{\mathrm{C}} 23.0, \delta_{3 \mathrm{H}} 1.83,3 \mathrm{H}\right)$ along with olefinic quaternary carbon $\left(\delta_{\mathrm{C}} 146.6\right)$. The HMBC correlations of $\mathrm{H}_{3}-13\left(\delta_{\mathrm{H}} 1.83\right)$ to $\mathrm{C}-7\left(\delta_{\mathrm{C}} 48.6\right), \mathrm{C}-11\left(\delta_{\mathrm{C}} 146.6\right)$, and C-12 $\left(\delta_{\mathrm{C}} 114.6\right)$, and of $\mathrm{H}_{2}-12\left(\delta_{\mathrm{H}} 4.77,4.90\right.$ brs each) with C-7 $\left(\delta_{\mathrm{C}} 48.6\right)$ and C-13 $\left(\delta_{\mathrm{C}} 23.0\right)$, and HMBC correlation of $\mathrm{H}-7\left(\delta_{\mathrm{H}} 2.54\right)$ with C-13 helped us to assign the isopropenyl unit at the C-7 position. The HMBC correlation of $\mathrm{H}_{3}-14\left(\delta_{\mathrm{H}} 1.00\right)$ to $\mathrm{C}-1$ $\left(\delta_{C} 50.2\right), C-9\left(\delta_{C} 71.9\right)$, and C-10 ( $\left.\delta_{C} 37.3\right)$, along with COSY cross peaks between $\mathrm{H}_{3}-14$ and $\mathrm{H}-10$ $\left(\delta_{\mathrm{H}} 2.14\right)$ revealed a hydroxyl group attached to C-9. The HMBC signals of $\mathrm{H}_{2}-2\left(\delta_{\mathrm{H}} 2.39,2.46 \mathrm{dd}\right.$ each) and $\mathrm{H}_{2}-8\left(\delta_{\mathrm{H}} 2.00,1.65\right.$, m each) with C-6 $\left(\delta_{\mathrm{C}} 73.3\right)$ supported the presence of another hydroxyl group located at C-6, thus the planar structure of compound 1 has been determined (Figure 2).

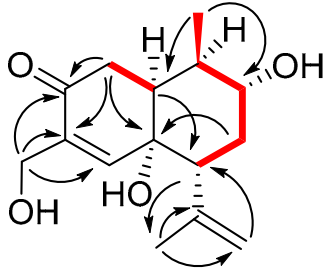

A

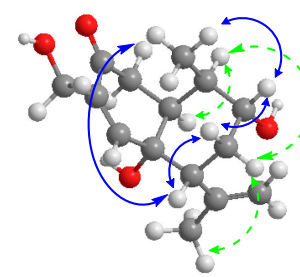

B

Figure 2. ${ }^{1} \mathrm{H}-{ }^{1} \mathrm{H}$ COSY, HMBC and NOESY correlations of compound 1. A: Key ${ }^{1} \mathrm{H}-{ }^{1} \mathrm{H}$ COSY (bold $-)$, and $\operatorname{HMBC}(\rightarrow)$ correlations. B: Key NOESY $\left(\stackrel{\wedge}{*}{ }^{\wedge}\right)$ correlations.

Table 1. ${ }^{1} \mathrm{H}$ and ${ }^{13} \mathrm{C}-\mathrm{NMR}$ spectroscopic data for compound $1-3$ ( $\delta$ in ppm, $J$ in $\left.\mathrm{Hz}\right)$.

\begin{tabular}{|c|c|c|c|c|c|c|}
\hline \multirow[t]{2}{*}{ Num. } & \multicolumn{2}{|l|}{$1^{a}$} & \multicolumn{2}{|l|}{$2^{b}$} & \multicolumn{2}{|l|}{$3^{b}$} \\
\hline & $\delta_{\mathbf{H}}$ & $\delta_{C}$ & $\delta_{\mathbf{H}}$ & $\delta_{C}$ & $\delta_{\mathbf{H}}$ & $\delta_{C}$ \\
\hline 1 & $2.21(\mathrm{dt}, 13.9,4.9)$ & 50.2 & & 143.7 & & 140.6 \\
\hline $2 \alpha$ & $2.46(\mathrm{dd}, 5.1,17.3)$ & 37.0 & $6.66(\mathrm{~s})$ & 112.8 & $6.68(\mathrm{~s})$ & 108.1 \\
\hline $2 \beta$ & $2.39(\mathrm{dd}, 13.9,17.3)$ & & & & & \\
\hline 3 & & 200.5 & & 152.3 & & 152.2 \\
\hline 4 & & 137.0 & & 120.7 & & 122.0 \\
\hline 5 & $6.85(\mathrm{~s})$ & 155.2 & $7.12(\mathrm{~s})$ & 133.1 & $6.93(\mathrm{~s})$ & 126.7 \\
\hline 6 & & 73.3 & & 127.8 & & 133.6 \\
\hline $7 \beta$ & $2.54(\mathrm{dd}, 13.43 .3)$ & 48.6 & $3.09(\mathrm{dd}, 8.6,5.6)$ & 44.0 & $2.79(\mathrm{t}, 2.7)$ & 38.9 \\
\hline $8 \alpha$ & $2.00(\mathrm{~m})$ & 36.8 & $2.00(\mathrm{~m})$ & 23.0 & $2.23(\mathrm{dt}, 12.42 .9)$ & 21.0 \\
\hline $8 \beta$ & $1.65(\mathrm{~m})$ & & $1.81(\mathrm{~m})$ & & $1.35(\mathrm{~m})$ & \\
\hline $9 \alpha$ & & 71.9 & $1.23(\mathrm{~m})$ & 31.2 & $1.39(\mathrm{dd}, 11.8,2.2)$ & 32.5 \\
\hline $9 \beta$ & 3. $47(\mathrm{td}, 10.9,4.4)$ & & $1.93(\mathrm{~m})$ & & $2.00(\mathrm{~m})$ & \\
\hline $10 \alpha$ & $2.14(\mathrm{~m})$ & 37.3 & $2.64(\mathrm{dq}, 14.27 .0)$ & 32.4 & & 72.3 \\
\hline 11 & & 146.6 & & 76.5 & & 75.9 \\
\hline $12 \mathrm{a}$ & 4.77 (s) & 114.6 & $3.57(\mathrm{~d} 11.1)$ & 67.7 & $2.85(\mathrm{~s})$ & 69.1 \\
\hline $12 \mathrm{~b}$ & $4.90(\mathrm{~s})$ & & $3.42(\mathrm{~d} 11.1)$ & & $2.85(\mathrm{~s})$ & \\
\hline 13 & $1.83(\mathrm{~s})$ & 23.0 & $1.14(\mathrm{~s})$ & 22.7 & $1.42(\mathrm{~s})$ & 22.5 \\
\hline 14 & $1.00(\mathrm{~d} 6.9)$ & 15.0 & $1.24(\mathrm{~d} 7.1)$ & 21.6 & $1.57(\mathrm{~s})$ & 22.0 \\
\hline 15 & $4.16(\mathrm{~d} 1.14)$ & 59.5 & $2.20(\mathrm{~s})$ & 15.5 & $2.25(\mathrm{~s})$ & 15.6 \\
\hline
\end{tabular}

The relative configuration of $\mathbf{1}$ was determined by NOESY spectra in a combination of coupling constant analysis. The observed NOESY correlations between the spin systems $\mathrm{H}_{3}-14\left(\delta_{\mathrm{H}} 1.00\right) / \mathrm{H}-9$ $\left(\delta_{\mathrm{H}} 3.47\right), \mathrm{H}-9 / \mathrm{H}_{\beta}-8\left(\delta_{\mathrm{H}} 1.65\right), \mathrm{H}_{\beta}-8 / \mathrm{H}-7\left(\delta_{\mathrm{H}} 2.54\right)$, and $\mathrm{H}-7 / \mathrm{H}-9$ suggested that $\mathrm{H}-9, \mathrm{H}-7, \mathrm{CH}_{3}-14$, and $\mathrm{H}_{\beta}-8$ were positioned in $\beta$-orientation, while correlations of $\mathrm{H}-1\left(\delta_{\mathrm{H}} 2.21\right) / \mathrm{H}-10\left(\delta_{\mathrm{H}} 2.14\right), \mathrm{H}-10 / \mathrm{H}_{\alpha}-8$ $\left(\delta_{\mathrm{H}} 2.00\right), \mathrm{H}_{\alpha}-8 / \mathrm{H}_{3}-13$ revealed that $\mathrm{H}-1, \mathrm{H}_{\alpha}-8, \mathrm{H}-10$ and the isopropenyl unit were $\alpha$-oriented. According to the coupling constants in the ${ }^{1} \mathrm{H}-\mathrm{NMR}, \delta_{\mathrm{H}} 2.39(J=13.9,17.3 \mathrm{~Hz})$ was assigned as $\mathrm{H}-2 \beta$ because the dihedral angle of $\mathrm{H}-2 \beta$ and $\mathrm{H}-1$ should be close to 180 , thus $\delta_{\mathrm{H}} 2.46(J=5.1,17.3 \mathrm{~Hz})$ was assigned as H-2 $\alpha$ [29]. The observed NOESY correlations between $\mathrm{H}-2 \beta / \mathrm{H}-7$ further proved this. The relative configuration of $6-\mathrm{OH}$ has been provisionally determined as $\alpha$ on the basis of alike chemical shift values of known compound 4, for which the configuration had been determined by X-ray experiment [6]. 
The absolute configuration could be determined by the application of helicity of $\alpha-\beta$ unsaturated ketone as described previously [30]. The observed negative cotton effect at $248 \mathrm{~nm}$ (Figure S12) was consistent with the helicity rule, hence the configuration of $\mathbf{1}$ was deduced to be $(-)-1 S, 6 R, 7 R, 9 R, 10 R-6,9,15$-trihydoxycadinan-4-en-3-one.

(+)-3,11,12-Trihydroxycalamenene (2) was prepared as a white amorphous powder and possessed a molecular formula of $\mathrm{C}_{15} \mathrm{H}_{22} \mathrm{O}_{3}$, which was determined by HRESIMS $\left(\mathrm{m} / \mathrm{z} 273.1471\right.$, $[\mathrm{M}+\mathrm{Na}]^{+}$calcd. 273.1461). IR spectra revealed the presence of hydroxyl $\left(3385 \mathrm{~cm}^{-1}\right)$ and phenolic $\left(1620 \mathrm{~cm}^{-1}\right)$ groups. The ${ }^{1} \mathrm{H}-\mathrm{NMR}$ spectrum (Table 1$)$ indicated two aromatic $\left(\delta_{\mathrm{H}} 6.66,7.12\right.$, s each) hydrogens, and two singlet $\left(\delta_{\mathrm{H}} 1.14,2.20\right.$, s each) and one doublet methyl $\left(\delta_{\mathrm{H}} 1.24, \mathrm{~d} J=7\right)$ groups.

The ${ }^{13} \mathrm{C}-\mathrm{NMR}$ and DEPT spectra (Table 1) exhibited fifteen carbon signals, including three methyls $\left(\delta_{C} 15.5,21.6,22.7\right)$, three methylenes $\left(\delta_{C} 23.0,31.2,67.7\right)$, four methines $\left(\delta_{C} 32.4,44.0,112.8,133.1\right)$, and five quaternary carbons $\left(\delta_{C} 76.5,120.7,127.8,133.1,152.3\right)$. Two aromatic methine signals $\left(\delta_{C}\right.$ $\left.112.8, \delta_{\mathrm{H}} 6.66 \mathrm{~s}\right),\left(\delta_{\mathrm{C}} 133.1, \delta_{\mathrm{H}} 7.12 \mathrm{~s}\right)$ together with four aromatic carbons $\left(\delta_{\mathrm{C}} 120.7,127.8,133.1\right.$, $152.3)$ suggesting a tetra-substituted aromatic spin system with a para configuration. Consideration of the unsaturation degrees and chemical shift characteristics, it was unambiguously proposed that compound 2 should be a bicyclic sesquiterpene with the calamenene skeleton [31-33].

The HMBC correlations of $\mathrm{H}-5\left(\delta_{\mathrm{H}} 7.12\right)$ with $\mathrm{C}-15\left(\delta_{\mathrm{c}} 15.5\right)$, and C-7 $\left(\delta_{\mathrm{C}} 44.0\right)$, and of $\mathrm{H}-2\left(\delta_{\mathrm{H}} 6.66\right)$ with $C-10\left(\delta_{C} 32.4\right)$, and $C-4\left(\delta_{C} 120.7\right)$ indicated that the two cycles were connected from $C-7$, and $\mathrm{C}-10$, which allowed us to fully determine the aromatic moiety [31]. The phenolic hydroxyl group at C-3 was assigned by the HMBC correlations of $\mathrm{H}_{3}-15\left(\delta_{\mathrm{H}} 2.20\right)$ to $\mathrm{C}-3\left(\delta_{\mathrm{C}} 152.3\right)$ and $\mathrm{C}-5\left(\delta_{\mathrm{C}} 133.1\right)$. Meanwhile, the correlations of $\mathrm{H}_{2}-12\left(\delta_{\mathrm{H}} 3.57,3.42, \mathrm{~d} \mathrm{~J}=11.1\right)$ with $\mathrm{C}-7\left(\delta_{\mathrm{C}} 44.0\right), \mathrm{C}-11\left(\delta_{\mathrm{C}} 76.5\right)$, and $\mathrm{C}-13\left(\delta_{C} 22.7\right)$, and of $\mathrm{H}_{3}-13\left(\delta_{\mathrm{H}} 1.14\right)$ with $\mathrm{C}-7\left(\delta_{\mathrm{C}} 44.0\right), \mathrm{C}-11\left(\delta_{C} 76.5\right)$, and $\mathrm{C}-12\left(\delta_{\mathrm{C}} 67.7\right)$ in the HMBC spectra corroborated the attachment of 1,2-isopropanediol group at position C-7. Furthermore, the HMBC correlations of $\mathrm{H}_{3}-14\left(\delta_{\mathrm{H}} 1.24, \mathrm{~d} J=7.1\right)$ to $\mathrm{C}-1\left(\delta_{\mathrm{C}} 143.7\right), \mathrm{C}-9\left(\delta_{\mathrm{C}} 31.2\right)$, and $\mathrm{C}-10\left(\delta_{\mathrm{C}} 32.4\right)$, along with COSY cross peaks between $\mathrm{H}_{3}-14\left(\delta_{\mathrm{H}} 1.24, \mathrm{~d} J=7.1\right) / \mathrm{H}-10\left(\delta_{\mathrm{H}} 2.64, \mathrm{dq} J=14.2,7.0\right) / \mathrm{H}_{2}-9$ $\left(\delta_{\mathrm{H}} 1.23,1.93\right) / \mathrm{H}_{2}-8\left(\delta_{\mathrm{H}} 1.81,2.00\right) / \mathrm{H}-7\left(\delta_{\mathrm{H}} 3.09\right)$ determined the cyclohexane ring. Hence the planar structure of compound 2 with the calamenene core skeleton [31] was established (Figure 3).

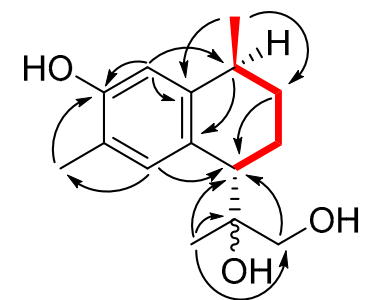

A

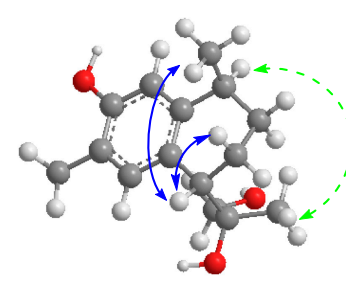

B

Figure 3. ${ }^{1} \mathrm{H}-{ }^{1} \mathrm{H}$ COSY, HMBC and NOESY correlations of compound 2. A: Key ${ }^{1} \mathrm{H}-{ }^{1} \mathrm{H}$ COSY (bold -), and $\operatorname{HMBC}(\rightarrow)$ correlations. B: Key NOESY $\left(\wedge_{\ldots}, A\right)$ correlations.

Comparison of the chemical shifts data of compound 2 with that of known compound 3,12-dihydroxycalamenene [31] suggesting that two compounds have a close resemblance in their planar structure, except that $C-11\left(\delta_{C} 76.5\right)$ in compound 2 was found to be an oxygenated quaternary carbon instead of a methine, as indicated by the HMBC correlations of $\mathrm{H}-7\left(\delta_{\mathrm{H}} 3.09\right), \mathrm{H}_{2}-12\left(\delta_{\mathrm{H}} 3.42\right.$, 3.57), and $\mathrm{H}_{3}-13\left(\delta_{\mathrm{H}} 1.14\right)$ with $\mathrm{C}-11$.

The relative configuration of 2 was assigned by detailed analysis of its NOESY spectra and the ${ }^{1} \mathrm{H}-\mathrm{NMR}$ coupling constants. The observed NOESY correlations between $\mathrm{H}_{3}-14\left(\delta_{\mathrm{H}} 1.24\right)$ and $\mathrm{H}-7$ ( $\delta_{\mathrm{H}} 3.09$ ) indicated that $\mathrm{H}_{3}-14$ and $\mathrm{H}-7$ were co-facial, while $\mathrm{H}_{3}-14$ and 1,2-isopropanediol group were trans to each other [34-37], unlike the cis conformations [31-33]. The above deductions were further proved by the NOESY cross peaks between $\mathrm{H}-10\left(\delta_{\mathrm{H}} 2.64\right)$ and $\mathrm{H}_{3}-13\left(\delta_{\mathrm{H}} 1.14\right)$. The relative stereochemistry at the cyclohexene ring was also deduced from the ${ }^{1} \mathrm{H}$ coupling constants [34]. The coupling constants between $\mathrm{H}-7$ and $\mathrm{H}-8 \alpha$ and between $\mathrm{H}-10$ and $\mathrm{H}-9 \beta$ were 8.6 and $14.2 \mathrm{~Hz}$, 
respectively, showing that these hydrogens have a trans-diaxial relationship, while the $\mathrm{CH}_{3}-14$ and the 1,2-isopropanediol group must both be equatorial and trans-oriented to each other [34]. OR experiment approved the compound to be dextrorotatory form $(+12.1)$, very similar to the reported compound $(+)-(1 S, 4 R)-7-m e t h o x y c a l a m e n e n e[34,35]$. Hence the compound was named as (+)-(7S, 10S)-3,11,12-trihydroxycalamenene. The absolute configuration of C-11 remained to be determined. CD spectra of 2 (Figure S24) was also recorded to give the information for the further research, which displayed a negative cotton effect at $238 \mathrm{~nm}$ and $276 \mathrm{~nm}$.

Compound $3(-)-3,10,11,12$-tetrahydroxycalamenene was isolated as white amorphous powder and its molecular formula $\mathrm{C}_{15} \mathrm{H}_{22} \mathrm{O}_{4}$ was established based on its HRESIMS data $(\mathrm{m} / z$ 289.1396, $[\mathrm{M}+\mathrm{Na}]^{+}$calcd. 289.1410). The IR spectra revealed the presence of hydroxyl $\left(3379 \mathrm{~cm}^{-1}\right)$ and phenolic $\left(1623 \mathrm{~cm}^{-1}\right)$ groups. The ${ }^{1} \mathrm{H}-\mathrm{NMR}$ spectrum (Table 1$)$ indicated two aromatic $\left(\delta_{\mathrm{H}} 6.68,6.93, \mathrm{~s}\right.$ each) hydrogen, and three methyl $\left(\delta_{\mathrm{H}} 1.42,1.57,2.25\right.$, s each) groups.

The ${ }^{13} \mathrm{C}-\mathrm{NMR}$ and DEPT spectra (Table 1 ) exhibited fifteen carbon signals, including three methyls $\left(\delta_{C} 15.6,22.0,22.5\right)$, three methylenes $\left(\delta_{C} 21.0,32.5,69.1\right)$, three methines $\left(\delta_{C} 38.9,108.1,126.7\right)$, and six quaternary carbons $\left(\delta_{C} 72.3,75.9,122.0,133.6,140.6,152.2\right)$. The similarity of the ${ }^{1} \mathrm{H}$ and ${ }^{13} \mathrm{C}$-NMR spectroscopic data of $\mathbf{3}$ with those of $\mathbf{2}$ (Table 1 ) suggested that they were analogues. Detailed comparison of the chemical shifts showed that $C-10$ in 3 was an oxygenated quaternary carbon $\left(\delta_{C} 72.3\right)$ rather than a methine $\left(\delta_{\mathrm{C}} 32.4, \delta_{\mathrm{H}} 2.64, \mathrm{qd}, J=14.2,7.0\right)$ in 2 . This inference was further confirmed by the HMBC correlations of $\mathrm{H}_{3}-14\left(\delta_{\mathrm{H}} 1.57\right)$ and $\mathrm{H}-2\left(\delta_{\mathrm{H}} 6.68\right)$ to $\mathrm{C}-10\left(\delta_{\mathrm{C}} 72.3\right)$. The whole planar structure of 3 was determined (Figure 4 ) by referencing the compound 2 , and by surveying the $2 \mathrm{D}$ NMR spectral data.

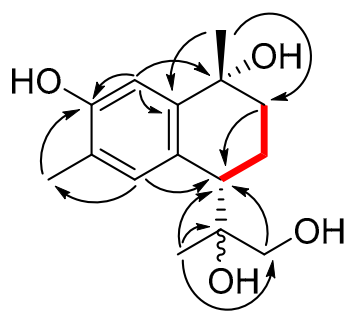

A

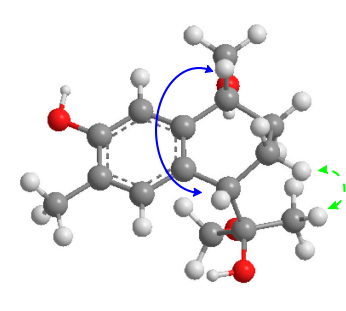

$\mathbf{B}$

Figure 4. ${ }^{1} \mathrm{H}-{ }^{1} \mathrm{H}$ COSY, HMBC and NOESY correlations of compound 3. A: Key ${ }^{1} \mathrm{H}-{ }^{1} \mathrm{H}$ COSY (bold -), and HMBC $(\rightarrow)$ correlations. B: Key NOESY $\left({ }^{\wedge},{ }^{\wedge}\right)$ correlations.

The relative configuration of $\mathbf{3}$ was assigned by detailed analysis of its NOESY spectra, in which $\mathrm{H}_{3}-14\left(\delta_{\mathrm{H}} 1.57\right)$ was correlated with $\mathrm{H}-7\left(\delta_{\mathrm{H}} 2.79, \mathrm{t}, J=2.7\right)$, illustrating the $\beta$-orientation of $\mathrm{H}-7$, while the 1,2-isopropanediol group was $\alpha$-oriented. The absence of correlations between $\mathrm{H}_{3}-14, \mathrm{H}_{3}-13$ and $\mathrm{H}_{2}-12$ also suggested that $\mathrm{H}_{3}-14$ and the 1,2-isopropanediol group were in trans conformation [34-37]. The ${ }^{1} \mathrm{H}$ coupling constant between $\mathrm{H}_{2}-8$ and $\mathrm{H}-7$ were $2.7 \mathrm{~Hz}$ in triplicate, indicating that $\mathrm{H}-7$ and $\mathrm{H}-8 \alpha, \mathrm{H}-8 \beta$ are in $e e$ and $a e$ formation. According to 3D molecular model and coupling constant of $\mathrm{H}-7$, the 1,2-isopropanediol group and 10-OH are in an axial position, which may be induced by the Van der Waals force between the $10-\mathrm{OH}$ and $11-\mathrm{OH}$ or $12-\mathrm{OH}$. The conformation change may also have resulted in the up fields shift of $\mathrm{H}_{2}-12$ from $\left(\delta_{\mathrm{H}} 3.57,3.42\right)$ in 2 to $\left(\delta_{2 \mathrm{H}} 2.85\right)$ in 3 , and the positive cotton effect at $263 \mathrm{~nm}$ in CD spectra (Figure S36) of 3. OR experiment approved the compound to be a laevoisomer, thus the compound was named as (-)-(7S, 10R)-3,10,11,12-tetrahydroxycalamenene.

\subsection{Antioxidant Activity of Isolated Compounds}

The antioxidant bioassay of compounds (1-8) was performed on human whole blood neutrophils initially, in which 8 showed potential to inhibit the generation of reactive oxygen species (ROS). Further study on isolated human polymorphonuclear cells or neutrophils exhibited that 8 possessed strong antioxidant effects with an $\mathrm{IC}_{50}$ value $=3.68 \pm 0.22 \mu \mathrm{M}$, comparing to the positive control Trolox with $\mathrm{IC}_{50}$ value $=77.23 \pm 1.62 \mu \mathrm{M}$. 


\subsection{Cytotoxic Activity of Isolated Compounds}

Compounds 2-8 were also evaluated for their cytotoxicity against human tumor cells: HL-60 (acute leukemia), HepG-2 (liver hepatocellular carcinoma), HCT-16 (colorectal carcinoma), BGC-823 (gastric carcinoma cell) using MTT assay. Unfortunately, all the tested compounds showed the $\mathrm{IC}_{50}$ value at more than $100 \mu \mathrm{M}$. Since different biochemical, molecular and genetic mechanisms are involved in the development and progression of these cancers, the treatment also requires the specific agents. Ideally, the test compounds should be assayed for their cytotoxic potential on large number of cancer cell lines in the preliminary screening, with the aim of finding a lead compound to study the mechanism of action to treat such malicious tumors, which might be a limiting factor for any significant cytotoxicity that is lacking in our study [38].

\section{Materials and Methods}

\subsection{Plant Material}

The stems of Kadsura heteroclita were collected in Shimen, Hunan, China, in September, 2014. The plant was identified by Prof. Wei Wang, and a voucher specimen (KH-shimen-201409) has been deposited in the TCM and Ethnomedicine Innovation \& Development International Laboratory, Innovative Materia Medica Research Institute, School of Pharmacy, Hunan University of Chinese Medicine.

\subsection{General and Solvents}

Optical rotations were measured on a Perking-Elmer 341-MC digital polarimeter. UV spectra were recorded on a TU-1900 spectrophotometer (Shimadzu Europa GmbH, Duisburg, Germany). Experimental CD spectra were recorded on a JASCO J-815 Circular Dichroism (CD) Spectropolarimeter (Jasco, Mary's Court Easton, MD, USA). A Hitachi 260-30 spectrometer was used for scanning IR spectroscopy. ID and 2D NMR spectra were performed on Bruker ARX-600 spectrometers ((Bruker Technology Co., Ltd., Karlsruhe, Germany) using TMS as the internal standard, with chemical shifts ( $\delta$ ) expressed in ppm and referenced to the solvent signals. HRESIMS were performed on a UPLC/xevo G2 Qtof spectrometer (Waters Corporation, Milford, MA, USA). Column chromatography (CC) was performed with silica gel (100-200 mesh and 200-300 mesh, Qingdao Marine Chemical, Inc., Qingdao, China), and Sephadex LH-20 (Pharmacia). Semipreparative HPLC was performed on an Agilent 1100 liquid chromatograph (Agilent Technologies, Santa Clara, CA, USA) with an Alltima $\mathrm{C}_{18}$ ( $5 \mu$ ODS $10 \mathrm{~mm} \times 250 \mathrm{~mm}$ ) column. Fractions were monitored by thin-layer chromatography (TLC) (Qingdao Marine Chemical Inc., Qingdao, China), and spots were visualized by heating the TLC silica gel plates sprayed with $10 \% \mathrm{H}_{2} \mathrm{SO}_{4}$ in EtOH $(10: 90, v / v)$. Petroleum ether (PE), ethyl acetate (EtOAc), $n$-butanol ( $n$-BuOH), dichloromethane $\left(\mathrm{CH}_{2} \mathrm{Cl}_{2}\right)$ and methanol $(\mathrm{MeOH})$ were purchased from Shanghai Titan Scientific Co., Ltd, Shanghai, China. MeOH (HPLC grade) and Water (HPLC grade) were purchased from Merck KGaA, 64271 Darmstadt, Germany.

\subsection{Extraction and Isolation}

The air-dried stems and roots of K. heteroclita $(400 \mathrm{~kg}$ ) were powdered and extracted with $95 \%$ aqueous ethanol $(3 \times 400 \mathrm{~L}, 3$ days each) at room temperature and concentrated under reduced pressure to afford a crude extraction $(8 \mathrm{~kg})$.

$1 \mathrm{~kg}$ of crude extraction was suspended in $\mathrm{H}_{2} \mathrm{O}(10 \mathrm{~L})$ and was partitioned between water and $n-\mathrm{BuOH}(10 \mathrm{~L})$ to afford the $n-\mathrm{BuOH}$ fraction, repeated for 3 times, the $n-\mathrm{BuOH}$ layer was combined and evaporated to yield a residue of $251.5 \mathrm{~g}$. Then $240.0 \mathrm{~g}$ of $n$-BuOH fraction was chromatographed on a silica gel column $(3.0 \mathrm{~kg}, 100-200$ mesh) using dichloromethane/methanol as elution solvents (from 99.8:0.2 to 0:100 gradient system), to afford fraction A-J.

Fraction C (35.1 g) was chromatographed using silica gel CC (0.9 kg, 200-300 mesh), eluted with a DCM/MeOH gradient system (99.8:0.2 to 0:100) to obtain ten fractions (Fr. C-1 to Fr. C-10). 
Fr. C-5 (3.1 g) was loaded to silica gel $(0.1 \mathrm{~kg}, 200-300 \mathrm{mesh})$ column and eluted with petroleum ether/ethyl acetate (90:10 to 20:80) to produce eight fractions (Fr. C-5-a to Fr. C-5-h). Fr. C-5-b (227.0 mg) was isolated by silica gel column (9.0 g, 200-300 mesh), by eluting with PE/EtOAc (40:60) to afford compound 5 (12.0 mg). Fr. C-10 (2.0 g) was subjected to silica gel CC (0.15 kg, 200-300 mesh) eluted with PE/EtOAc (80:20 to 0:100) to give twelve fractions (Fr. C-10-1 to Fr. C-10-12). Fr. C-10-7 was purified by semipreparative HPLC, with a solvent of $\mathrm{MeOH} / \mathrm{H}_{2} \mathrm{O}(3 \mathrm{ml} / \mathrm{min}$, 75:25), to afford $8(4.3 \mathrm{mg})$.

Fraction D (20.6 g) was separated over silica gel CC ( $0.6 \mathrm{~kg}$, 200-300 mesh) with a gradient elution of DCM/MeOH (99.5:0.5 to 0:100) to give ten fractions (Fr. D-1 to Fr. D-10). Fr. D-3 (1.5 g) was repeated eluting on silica gel CC (0.2 kg, 200-300 mesh) and produced six subfractions (D-3-a to D-3-f), D-3-d $(350.0 \mathrm{mg})$ was purified by silica gel CC ( $50.0 \mathrm{~g}, 200-300 \mathrm{mesh})$ eluting with PE/EtOAc (90:10 to 0:100) to yield two crystals $4(6.5 \mathrm{mg})$ and $\mathbf{6}(120.5 \mathrm{mg})$. Fraction D-5 $(1.2 \mathrm{~g})$ was chromatographed by silica gel CC $(0.1 \mathrm{~kg}, 200-300$ mesh) eluted with PE/EtOAc (90:10 to 0:100) to give six fractions (Fr. D-5-a to Fr. D-5-f). Fr. D-5-a (214.7 mg) was applied to another silica gel CC (20.0 g, 200-300 mesh) eluted with PE/EtOAc (80:20) to give six fractions (Fr. D-5-a-1 to Fr. D-5-a-6). Fr. D-5-a-5 (42.0 mg) was purified by semipreparative HPLC $\left(2 \mathrm{~mL} / \mathrm{min}, \mathrm{MeOH} / \mathrm{H}_{2} \mathrm{O}, 75: 25\right)$ to yield $3(1.8 \mathrm{mg})$ and $2(7.6 \mathrm{mg})$ respectively. The Fr. D-6 (1.0 g) was repeated on silica gel $(0.1 \mathrm{~kg}, 200-300$ mesh) column eluting with PE/EtOAc (50:50 to 0:100) to yield eight fractions (Fr. D-6-a to Fr. D-6-h). Fr. C-6-f (201.3 mg) was separated by sephadex LH 20 (10.0 g) column with the washing solvent methanol/chloroform (1:1), to produce four fractions (Fr. C-6-f-1 to C-6-f-4). Fr. C-6-f-2 (21.7 mg) was purified by semi prepare HPLC $\left(\mathrm{MeOH} / \mathrm{H}_{2} \mathrm{O}, 75: 25\right)$ to obtain compound $1(2.1 \mathrm{mg})$. Fr. D-7 $(0.5 \mathrm{~g})$ was subjected to silica gel CC (50.0 g, 200-300 mesh) eluted with PE/EtOAc (80:20 to 0:100) to provide eight fractions (Fr. D-7-a to Fr. D-7-h). Fr. D-7-g (54.8 mg) was purified by semipreparative HPLC, with a solvent system of $\mathrm{MeOH} / \mathrm{H}_{2} \mathrm{O}$ (3 mL/min, 70:30), to afford compounds 7 (10.2 mg).

\subsection{Spectroscopic Data of New Compounds}

$6 \alpha, 9 \alpha, 15$-Trihydroxycadinan-4-en-3-one (1): white solid (MeOH); $[\alpha]_{\mathrm{D}}^{20}-20.0($ c 0.25, $\mathrm{MeOH}) ; \mathrm{UV}(\mathrm{MeOH})$ $\lambda_{\max }(\log \varepsilon) 230(3.10) \mathrm{nm} ; \mathrm{CD}(c 0.50, \mathrm{MeOH}) \lambda_{\max }(\Delta \varepsilon) 248(-4.42), 270(+3.66), 332(+4.99) \mathrm{nm} ; \mathrm{IR}$ $v_{\max } 3410,2930,1713,1668,1606,1283,1255,1098 \mathrm{~cm}^{-1} ;{ }^{1} \mathrm{H}$ and ${ }^{13} \mathrm{C}-\mathrm{NMR}$ data, see Table 1 ; positive HRESIMS $m / z 289.1419[\mathrm{M}+\mathrm{Na}]^{+}$(calcd for $\mathrm{C}_{15} \mathrm{H}_{22} \mathrm{O}_{4} \mathrm{Na}, 289.1416$ ).

(+)-3,11,12-Trihydroxycalamenene (2): white, amorphous solid; $[\alpha]_{\mathrm{D}}^{20}+12.1$ (c 1.9, $\left.\mathrm{MeOH}\right)$; UV(MeOH) $\lambda_{\max }(\log \varepsilon) 283(3.41) \mathrm{nm} ; \mathrm{CD}(c 0.33 \mathrm{MeOH}) \lambda_{\max }(\Delta \varepsilon) 238(-5.49) \mathrm{nm}, 276$ (-8.68); IR $v_{\max }$ 3385, 2960, 2932, 2873, 1620, 1505, 1457, 1381, 1260, 1187, 1114, $1039 \mathrm{~cm}^{-1} ;{ }^{1} \mathrm{H}$ and ${ }^{13} \mathrm{C}-\mathrm{NMR}$ data, see Table 1; positive HRESIMS $m / z 273.1471[\mathrm{M}+\mathrm{Na}]^{+}$(calcd for $\mathrm{C}_{15} \mathrm{H}_{22} \mathrm{O}_{3} \mathrm{Na}, 273.1461$ ).

(-)-3,10,11,12-Tetrahydroxy-calamenene (3): white, amorphous solid; $[\alpha]_{\mathrm{D}}^{20}-2.2($ c $0.45, \mathrm{MeOH})$; $\mathrm{UV}(\mathrm{MeOH}) \lambda_{\max }(\log \varepsilon) 220(3.90) \mathrm{nm}, 280(3.45) \mathrm{nm} ; \mathrm{CD}\left(c\right.$ 0.12, MeOH) $\lambda_{\max }(\Delta \varepsilon) 215(+11.85), 237$ (-2.42), 263 (+6.16) nm; IR $v_{\max } 3379,2932,1623,1463,1421,1376,1196,1044 \mathrm{~cm}^{-1} ;{ }^{1} \mathrm{H}$ and ${ }^{13} \mathrm{C}-\mathrm{NMR}$ data, see Table 1; positive HRESIMS $m / z 289.1396[\mathrm{M}+\mathrm{Na}]^{+}$(calcd for $\mathrm{C}_{15} \mathrm{H}_{22} \mathrm{O}_{4} \mathrm{Na}$, 289.1416).

\subsection{Antioxidant Assay}

Chemiluminescence assay was utilized to measure the antioxidant activity. It is a sensitive method to measure the inhibition of ROS production [39]. Phorbol 12-myristate 13-acetate (PMA) is used as an inducer for the generation of various ROS by macrophages and neutrophils, and PMA is used as an activator of protein kinase $C$ and activator of NADPH oxidase in our study [11].

Different concentrations of samples were incubated with either diluted whole blood $40 \mu \mathrm{L}$ (1:25 dilution in sterile PBS, pH 7.4) or PMN $40 \mu \mathrm{L}$ (Polymorphonuclear cells, $1 \times 10^{6} / \mathrm{mL}$ ) suspended in HBSS $^{++}$. The cells were stimulated with $40 \mu \mathrm{L}$ of opsonized zymosan followed by luminol as enhancer and then $\mathrm{HBSS}^{++}$was added to adjust the final volume to $200 \mu \mathrm{L}$. The final concentrations of the samples in the mixture were 20, 10, 5, 2.5 and $0.625 \mu \mathrm{M}$. Microplates were then incubated at $22^{\circ} \mathrm{C}$ for 
$30 \mathrm{~min}$. The results were measured by Enspire Multimode Plate Reader (PerkinElmer, Inc., Winter Street Waltham, MA, USA), as counts per second (CPS). Inhibition percentage (\%) calculated as:

$$
\text { Inhibition percentage }(\%)=100-\left(\mathrm{CPS}_{\text {test }} / \mathrm{CPS}_{\text {control }}\right) \times 100
$$

\subsection{Cytotoxicity Assays}

The cytotoxicity assay was performed using an MTT assay [40], the experiment method referenced to the reported literature [11] and the following human tumor cell lines were used: HL-60 (acute leukemia), HepG-2 (liver hepatocellular carcinoma), HCT-16 (colorectal carcinoma), BGC-823 (gastric carcinoma cell). Each tumor cell line was exposed to test compounds in triplicate for $48 \mathrm{hr}$., with Taxol used as a positive control substance.

Supplementary Materials: The following are available online at http://www.mdpi.com/1420-3049/24/9/1664/s1, Figures S1-S12: 1D and 2D NMR, HRESIMS, UV, IR, CD spectra of compound 1. Figures S13-S24: 1D and 2D NMR, HRESIMS, UV, IR, CD spectra of compound 2. Figures S25-S36: 1D and 2D NMR, HRESIMS, UV, IR, CD spectra of compound 3. Figures S37-S46: H and C-NMR spectra of compounds 4-8.

Author Contributions: W.W. (corresponding author) and D.-f.L. conceived and designed the idea of the study; L.C., N.S. contributed to isolating work and paper writing; Y.J., B.L., C.P. performed the NMR spectra elucidating; M.C., W.S. contributed to the HRESI-MS, IR and other spectra experiment work; S.T. designed the content of bioassays; W.W., M.I.C., A.-u.-R. contributed to revision, funding acquisition, project administration and supervision. All of the authors read and approved the final manuscript.

Funding: This work was supported in part by National Natural Science Foundation of China $(81673579,81874369$ and 81374062), Ministry of Science and Technology of P.R.China (2018FY100703) and Hunan Science and Technology Department (2019JJ50315, 2018SK 2110 and 2081).

Acknowledgments: The authors would like to thank Bin Liu in Hunan University for valuable suggestion in Bioassay.

Conflicts of Interest: The authors declare no conflict of interest.

\section{References}

1. Hu, Z.X.; Shi, Y.M.; Wang, W.G.; Li, X.N.; Du, X.; Liu, M.; Li, Y.; Xue, Y.B.; Zhang, Y.H.; Pu, J.X.; et al. Kadcoccinones A-F, New Biogenetically related lanostane-type triterpenoids with diverse skeletons from Kadsura coccinea. Org. Lett. 2015, 17, 4616-4619. [CrossRef]

2. $\quad$ Liang, C.Q.; Shi, Y.M.; Wang, W.G.; Hu, Z.X.; Li, Y.; Zheng, Y.T.; Li, X.N.; Du, X.; Pu, J.X.; Xiao, W.L.; et al. Kadcoccinic acids A-J, triterpene acids from Kadsura coccinea. J. Nat. Prod. 2015, 78, 2067-2073. [CrossRef]

3. Shi, Y.M.; Xiao, W.L.; Pu, J.X.; Sun, H.D. Triterpenoids from the Schisandraceae family: an update. Nat. Prod. Rep. 2015, 32, 353-410. [CrossRef] [PubMed]

4. Xiao, W.L.; Li, R.T.; Huang, S.X.; Pu, J.X.; Sun, H.D. Triterpenoids from the Schisandraceae family. Nat. Prod. Rep. 2008, 25, 871-891. [CrossRef] [PubMed]

5. Hu, Z.X.; Shi, Y.M.; Wang, W.G.; Tang, J.W.; Zhou, M.; Du, X.; Zhang, Y.H.; Pu, J.X.; Sun, H.D. Structural characterization of Kadcoccinin A: a sesquiterpenoid with a tricyclo [4.4.0.03,10] decane scaffold from Kadsura coccinea. Org. Lett. 2016, 18, 2284-2287. [CrossRef] [PubMed]

6. Su, W.; Zhao, J.P.; Hu, J.; Yang, M.; Jacob, M.; Cai, X.; Zeng, R.; Chen, S.H.; Huang, H.Y.; Khan, I.; et al. Two new bicyclic sesquiterpenes from the stems of Kadsura heteroclita. Nat. Prod. Res. 2014, 28, 1197-1201. [CrossRef] [PubMed]

7. Deng, L.Q.; Wang, G.W.; Zhou, S.Y.; Ge, J.Q.; Liao, Z.H.; Chen, D.F.; Chen, M. Renchangianins F and G: two new sesquiterpenoids from Kadsura renchangiana. J. Asian Nat. Prod. Res. 2017, 19, 157-163. [CrossRef] [PubMed]

8. Poornima, B.; Siva, B.; Shankaraiah, G.; Venkanna, A.; Nayak, V.L.; Ramakrishna, S.; Venkat Rao, C.; Babu, K.S. Novel sesquiterpenes from Schisandra grandiflora: isolation, cytotoxic activity and synthesis of their triazole derivatives using "click" reaction. Eur. J. Med. Chem. 2015, 92, 449-458. [CrossRef]

9. Venkanna, A.; Siva, B.; Poornima, B.; Vadaparthi, P.R.; Prasad, K.R.; Reddy, K.A.; Reddy, G.B.; Babu, K.S. Phytochemical investigation of sesquiterpenes from the fruits of Schisandra chinensis and their cytotoxic activity. Fitoterapia 2014, 95, 102-108. [CrossRef] 
10. Tsai, Y.C.; Cheng, Y.B.; Lo, I.W.; Cheng, H.H.; Lin, C.J.; Hwang, T.L.; Kuo, Y.C.; Liou, S.S.; Huang, Y.Z.; Kuo, Y.H.; et al. Seven new sesquiterpenoids from the fruits of Schisandra sphenanthera. Chem. Biodivers. 2014, 11, 1053-1068. [CrossRef]

11. Liu, Y.B.; Yang, Y.P.; Tasneem, S.; Hussain, N.; Daniyal, M.; Yuan, H.W.; Xie, Q.L.; Liu, B.; Sun, J.; Jian, Y.Q.; et al. Lignans from Tujia Ethnomedicine Heilaohu: Chemical characterization and evaluation of their cytotoxicity and antioxidant activities. Molecules 2018, 23, 2147. [CrossRef] [PubMed]

12. Liu, J.S.; Qi, Y.D.; Lai, H.W.; Zhang, J.; Jia, X.G.; Liu, H.T.; Zhang, B.G.; Xiao, P.G. Genus Kadsura, a good source with considerable characteristic chemical constituents and potential bioactivities. Phytomedicine 2014, 21, 1092-1097. [CrossRef]

13. Pu, J.X.; Yang, L.M.; Xiao, W.L.; Li, R.T.; Lei, C.; Gao, X.M.; Huang, S.X.; Li, S.H.; Zheng, Y.T.; Huang, H.; et al. Compounds from Kadsura heteroclita and related anti-HIV activity. Phytochemistry 2008, 69, 1266-1272. [CrossRef] [PubMed]

14. Yu, H.H.; Zeng, R.; Li, X.; Song, H.P.; Wei, Y.X.; Li, R.Y.; Li, T.; Liu, L.; Wang, W.; Cai, X. Tujia ethnomedicine Xuetong suppresses onset and progression of adjuvant-induced arthritis in rats. Chin. Phar. Bull. 2016, 32, 1427-1432.

15. Yu, H.H.; Zeng, R.; Lin, Y.; Li, X.; Tasneema, S.; Yang, Z.; Qiu, Y.X.; Li, B.; Wang, Y.H.; Cai, X.; Wang, W. Kadsura heteroclita stem suppresses the onset and progression of adjuvantinduced arthritis in rats. Phytomedicine 2019, 58, 152876. [CrossRef] [PubMed]

16. Wang, W.; Liu, J.Z.; Yang, M.; Sun, J.H.; Wang, X.M.; Liu, R.X.; Guo, D.A. Simultaneous determination of six major constituents in the stems of Kadsura heteroclita by LC-DAD. Chromatographia 2006, 64, 297-302. [CrossRef]

17. Wang, W.; Xu, Z.R.; Yang, M.; Liu, R.X.; Wang, W.X.; Liu, P.; Guo, D.A. Structural determination of seven new triterpenoids from Kadsura heteroclita by NMR techniques. Magn. Reson. Chem. 2007, 45, 522-526. [CrossRef] [PubMed]

18. Wang, W.; Liu, J.Z.; Han, J.; Xu, Z.R.; Liu, R.X.; Liu, P.; Wang, W.X.; Ma, X.C.; Guan, S.H.; Guo, D.A. New triterpenoids from Kadsura heteroclita and their cytotoxic activity. Planta Med. 2006, 72, 450-457. [CrossRef]

19. Wang, W.; Liu, J.Z.; Ma, X.C.; Yang, M.; Wang, W.X.; Liu, P.; Guo, D.A. Three new cyclolanostane triterpenoids from the ethanol extract of the stems of Kadsura heteroclta. Helv. Chim. Acta. 2006, 89, 1888-1893. [CrossRef]

20. Su, W.; Zhao, J.P.; Yang, M.; Yan, H.W.; Pang, T.; Chen, S.H.; Huang, H.Y.; Zhang, S.H.; Ma, X.C.; Guo, D.A.; et al. A coumarin lignanoid from the stems of Kadsura heteroclita. Bioorg. Med. Chem. Lett. 2015, 25, 1506-1508. [CrossRef]

21. Wang, W.; Liu, J.Z.; Liu, R.X.; Xu, Z.R.; Yang, M.; Wang, W.X.; Liu, P.; Sabia, G.; Wang, X.M.; Guo, D.A. Four new lignans from the stems of Kadsura heteroclita. Planta Med. 2006, 72, 284-288. [CrossRef]

22. Wang, W.; Ma, X.C.; Liu, P.; Liu, R.X.; Guan, S.H.; Guo, D.A. Two new dibenzylbutyrolactone type lignans from Kadsura heteroclita. Nat. Prod. Comm. 2006, 1, 109-112. [CrossRef]

23. Bohlmann, F.; Giencke, W. Naturally occurring terpene derivatives. 456. Synthesis of isoepicubenol. Tetrahedron 1983, 39, 443-447. [CrossRef]

24. Locksley, H.D.; Fayez, M.B.; Radwan, A.S.; Chari, V.M.; Cordell, G.A.; Wagner, H. Constituents of local plants. J. Med. Plant Res. (Planta Med.) 1982, 45, 20-22. [CrossRef] [PubMed]

25. Sung, T.V.; Steffan, B.; Steglich, W.; Klebe, G.; Adam, G. Sesquiterpenoids from the roots of Homalomena aromatica. Phytochemistry 1992, 31, 3515-3520. [CrossRef]

26. Jung, K.Y.; Kim, D.S.; Oh, S.R.; Lee, I.S.; Lee, J.J.; Lee, H.Y.; Shim, D.H.; Kim, E.H.; Cheong, C.J. Sesquiterpene components from the flower buds of Magnolia fargesii. Arch. Pharm. Res. 1997, 20, 363-367. [CrossRef] [PubMed]

27. Wells, J.M.; Cutler, H.G.; Cole, R.J. Toxicity and plant growth regulator effects of cytochalasin H isolated from Phomopsis sp. Can. J. Microbiol. 1976, 22, 1137-1143. [CrossRef] [PubMed]

28. Lee, J.; Yi, J.M.; Kim, H.; Lee, Y.J.; Park, J.S.; Bang, O.S.; Kim, N.S. Cytochalasin H, an Active Anti-angiogenic Constituent of the Ethanol Extract of Gleditsia sinensis Thorns. Biol. Pharm. Bull. 2014, 37, 6-12. [CrossRef] [PubMed]

29. Zhu, H.; Hua, X.X.; Gong, T.; Pang, J.; Hou, Q.; Zhu, P. Hypocreaterpenes A and B, cadinane-type sesquiterpenes from a marine-derived fungus, Hypocreales sp. Phytochem. lett. 2013, 6, 392-396. [CrossRef] 
30. Djerassi, C.; Records, R.; Bunnenberg, E.; Mislow, K.; Moscowitz, A. Inherently dissymetric chromophores. Optical rotatory dispersion of $\alpha, \beta$-unsaturated ketones and conformational analysis of cyclohexenones. J. Am. Chem. Soc. 1962, 84, 870-872. [CrossRef]

31. Silva, G.H.; Teles, H.L.; Zanardi, L.M.; Marx Young, M.C.; Eberlin, M.N.; Hadad, R.; Pfenning, L.H.; Costa-Neto, C.M.; Castro-Gamboa, I.; da Silva Bolzani, V.; et al. Cadinane sesquiterpenoids of Phomopsis cassiae, an endophytic fungus associated with Cassia spectabilis (Leguminosae). Phytochemistry 2006, 67, 1964-1969. [CrossRef]

32. Sun, Y.Q.; Yu, B.X.; Wang, X.L.; Tang, S.B.; She, X.G.; Pan, X.F. Stereoselective Syntheses of Four Diastereomers of 3,9,12-Trihydroxycalamenene via a Benzobicyclo [3.3.1] Intermediate. J. Org. Chem. 2010, 75, 4224-4229. [CrossRef]

33. Nagashima, F.; Momosaki, S.; Watanabe, Y.; Takaoka, S.; Huneck, S.; Asakawa, Y. Sesquiterpenoids from the liverworts Bazzania trilobata and Porella canariensis. Phytochemistry 1996, 42, 1361-1366. [CrossRef]

34. Nabeta, K.; Katayama, K.; Nakagawara, S.; Katoh, K. Sesquiterpenes of cadinane type from cultured cells of the liverwort, Heteroscyphus planus. Phytochemistry 1993, 32, 117-122. [CrossRef]

35. Salmoun, M.; Braekman, J.C.; Ranarivelo, Y.; Rasamoelisendra, R.; Ralambomanana, D.; Dewelle, J.; Darro, F.; Kiss, R. New calamenene sesquiterpenes from Tarenna madagascariensis. Nat. Prod. Res. 2007, 21, 111-120. [CrossRef]

36. Bohlmann, F.; Wallmeyer, M.; Jakupovic, J.; Ziesche, J. Diterpenes and sesquiterpenes from Osteospermum species. Phytochemistry 1983, 22, 1645-1651. [CrossRef]

37. Morimoto, M.; Cantrell, C.L.; Libous-Bailey, L.; Duke, S.O. Phytotoxicity of constituents of glandular trichomes and the leaf surface of camphorweed, Heterotheca subaxillaris. Phytochemistry 2009, 70, 69-74. [CrossRef] [PubMed]

38. Pejin, B.; K Jovanovic, K.; Mojovic, M.; G Savic, A. New and highly potent antitumor natural products from marine-derived fungi: Covering the period from 2003 to 2012. Curr. Top. Med. Chem. 2013, 13, 2745-2766. [CrossRef]

39. Tarpey, M.M.; Fridovich, I. Methods of detection of vascular reactive species: Nitric oxide, superoxide, hydrogen peroxide, and peroxynitrite. Circ. Res. 2001, 89, 224-236. [CrossRef]

40. Schauer, U.; Krolikowski, I.; Rieger, C.H. Detection of activated lymphocyte subsets by fluorescence and MTT staining. J. Immunol. Methods. 1989, 116, 221-227. [CrossRef]

Sample Availability: Samples of the compounds 1-8 are available from the authors.

(C) 2019 by the authors. Licensee MDPI, Basel, Switzerland. This article is an open access article distributed under the terms and conditions of the Creative Commons Attribution (CC BY) license (http://creativecommons.org/licenses/by/4.0/). 